\title{
Escravos letrados: uma página (quase) esquecida
}

Marialva Carlos Barbosa

\section{Resumo}

0 artigo procura mostrar que, apesar de ser pouco referenciadas, a leitura e a escrita dos escravos do século XIX no Brasil podem ser perfeitamente recuperadas a partir de múltiplos indícios. 0 estigma da imersão dos escravos num mundo cuja prevalência era a oralidade encobre as suas múltiplas possibilidades de letramento e leitura numa sociedade perpassada pelos impressos.

\section{Palavras-chave}

Escravos. Leitura. Impressão.

\section{Marialva Carlos Barbosa | mcb1@terra.com.br}

Doutora em História pela Universidade Federal Fluminense - UFF. Professora titular da UFF e professora do quadro permanente do Programa de Pós-Graduação em Comunicação da UFF. Possui pós-doutorado em Comunicação pelo LAIOS-CNRS (Paris/França) É Diretora Científica da INTERCOM e Presidente da Associação Brasileira de Pesquisadores de História da Mídia - ALCAR.

\section{Introdução}

Quando se fala em história da imprensa no Brasil e há qualquer referência ao chamado período Abolicionista, o que se destaca é a participação dos jornais e de alguns dirigentes dessas publicações no debate em favor ou contra a escravidão. De tal forma que alguns desses periódicos recebem o epíteto de "jornais abolicionistas" e seus líderes são cultuados, pela historiografia em geral e da imprensa, em particular, como nomes imprescindíveis no processo de término da escravidão no país.

Os periódicos - tanto os que representavam um discurso mais conservador, quanto os que se auto-definiam como libertários - espelhavam as idéias predominantes do período e, mesmo quando publicavam veementes defesas contra o escravismo, produziam apologias disfarçadas ou não de racismo e disseminavam de maneira mais ou menos subliminar preconceitos contra os negros. Os mesmos jornais que acolhiam as falas contra a escravidão, principalmente à medida que a campanha abolicionista se espraiava e a crise do escravismo se tornava mais evidente, 
eram os que também representavam em textos e em imagens os escravos como um outro incomum e com características que, por vezes, fugiam à humanidade.

Não há quase nenhuma referência aos escravos como sujeitos históricos e menos ainda às suas capacidades de produção de significados a partir de códigos comunicacionais dominantes nessa sociedade. Há uma espécie de silêncio sobre a sua imersão no mundo do letramento e da leitura. Não há quase referência às suas habilidades desenvolvidas num mundo repleto de signos escritos e visuais.

Falar da relação imprensa e mundo dos escravos é, portanto, mostrar não apenas a forma como os periódicos se referiam a eles ou realçar os discursos mais ou menos favoráveis à Abolição. Também não é somente reconhecer que, sendo objetos discursivos dessa imprensa, tiveram suas vidas influenciadas por essas falas. Essa relação enseja que se pense nas marcas que eles, como atores e sujeitos da história, deixaram nos jornais. Inclusive as marcas de suas leituras plurais.

Suas marcas e feridas expostas nas descrições dos anúncios procurando pelos que reiteradamente se rebelavam e fugiam do cativeiro estão contidas nesses periódicos, que se dividiam com mais ou menos fervor em favor de sua causa. Nos jornais e revistas do período, aparecem subrepticiamente seus rostos e seus corpos. Massa amorfa, apresentada de maneira indiferenciada como coisa, os homens de cor, os "pretos" ou as "peças", como chegavam ser referidos nos anúncios, viviam em cidades onde as múltiplas sociabilidades permitiam misturas que, certamente, faziam com que tomassem conhecimento do que aquelas publicações falavam a seu respeito.

A proximidade que alguns experimentavam da casa dos seus proprietários - exercendo funções domésticas ou mesmo como escravos de ganho -, ou da cidade, já que circulavam por suas ruas, praças e vielas, leva-nos a buscar indícios de suas leituras de primeira, de segunda ou de terceira natureza e permite dizer que não era apenas passivamente que figuravam nas páginas das publicações. A venda avulsa de periódicos, como a Gazeta de Notícias, a partir de 1875, se fazia com 0 grito estridente dos filhos de escravos que apregoavam pelas ruas do Rio de Janeiro o novo jornal.

Há muitos outros exemplos desse lugar que ocupavam como pregoeiros e vendedores de jornais. Há indícios de que muitos sabiam ler ou, pelo menos, escutavam aquelas notícias que ecoavam também pelas ruas, praças e casas grandes. E quando não havia leitura, havia muitas vezes maior grau de letramento entre muitos desses cativos que habitavam as capitais.

A sociedade dos idos de 1870 não era dividida apenas entre senhores e escravos. Havia escravos de ganho e de aluguel e libertos, exercendo profissões especializadas, como as de carpinteiros e pedreiros, o que certamente 
fazia com que lidassem, pelo menos, com códigos numéricos. Havia ainda os que manejavam as prensas tipográficas, o que fazia com que as letras impressas fossem parte de seu cotidiano do trabalho. Havia também os trabalhadores livres nacionais que exerciam as mais diversas profissões - artesãos, comerciários, empregados das indústrias têxteis -, e os imigrantes europeus. No universo das grandes cidades, 0 contingente de escravos era representativo. Em 1870, existiam na cidade do Rio de Janeiro 274.972 habitantes, sendo que deste total 18\%, ou seja, 48.939 eram escravos ${ }^{1}$.

Esse texto é, pois, dedicado à relação imprensa e mundo dos escravos a partir de uma ótica privilegiada: a maneira como se constituiam como leitores de primeira, de segunda ou de terceira natureza, inclusive dos periódicos².

Como enfatiza Marco Morel (2008, p. 81), deixando as marcas de seus corpos, gestos, resistências, violências e sofrimentos na imprensa, dividindo opiniões dos jornais e jornalistas, sendo agentes intermediários na venda dos periódicos, possibilitando a explosão de um tipo mais recorrente de anúncios, os das fugas sistemáticas do cativeiro e, finalmente, como leitores, havia uma ligação estreita entre escravos e imprensa no Brasil do século XIX.

\section{Escravos leitores}

Uma ilustração publicada em 15 de outubro de 1887 na Revista Ilustrada ${ }^{3}$, periódico de circulação expressiva na então capital do Império, mostra claramente uma cena de leitura dos escravos. Sob a legenda "um fazendeiro também fez uma descoberta que 0 deixou embatucado! Um escravo lia no eito para os seus parceiros ouvirem, um discurso abolicionista do Conselheiro Dantas", aparece um cenário rural. Onze escravos formam uma roda: no centro, um deles segura um jornal. 0 título do periódico se deixa antever: $O$ Paiz. Segurando-o, lê. Os outros, sete homens, duas mulheres e uma criança, escutam, boquiabertos. Apóiam-se em enxadas e fazem (podemos supor) o mais absoluto silêncio. Escutam com atenção as palavras que do mundo impresso invadem o mundo oral.

Relatório de 1873. Diretoria Geral de Estatística Rio: Tipografia Franco-Americana, 1874. No começo do século XIX, o Brasil tinha 3 milhões de habitantes, sendo de 1 milhão o número de escravos. A população da cidade era avaliada no ano de 1808 em 60 mil habitantes, sendo a metade constituída por escravos (RIOS FILHO, 1946, p. 59). Utilizando-se de vasta documentação, 0 mesmo autor estabelece 0 seguinte cálculo: 0 Brasil recebeu, em quatro séculos de introdução de escravos, aproximadamente 3 milhões e 700 mil africanos, sendo que deste total só no século XIX (até 1856) entrou no país 1 milhão e 600 mil (Idem, p. 264).

Esse artigo está inserido num projeto maior cujo objetivo é recuperar as misturas do mundo oral e letrado e também as leituras dos escravos no Brasil do século XIX.

A Revista llustrada foi fundada pelo italiano Angelo Agostini, em 1876, e o primeiro número circulou em $1^{\circ}$ de janeiro daquele ano, deixando de circular em 1898. Chegando ao Brasil em 1859, Agostini fixa residência inicialmente em São Paulo, onde funda 0 Diabo Coxo (1864) e 0 Cabrião (1866). Em 1867, Agostini muda-se para o Rio de Janeiro, participando de 0 Arlequim, trabalhando posteriormente em A Vida Fluminense (1868-1875), de onde saiu para fundar a Revista Ilustrada (SODRÉ, 1966). Sobre a Revista Ilustrada e Angelo Agostini conforme a excelente tese de Balaban (2005). 
A cena mostra mais do que uma prática de leitura e a possibilidade de os escravos serem, de fato, leitores dos jornais que circulam pelos campos e pelas cidades. Leitores de primeira natureza, como o que ocupa o centro da roda, na leitura dirigida aos ouvidos dos que escutam. Leitores de segunda natureza, como os dez outros que, em atitude de espera, ouvem atentamente as palavras que ecoam sob a forma de voz. $\mathrm{Ou}$ leitores de terceira natureza, como os que, na progressão da palavra impressa sob a forma de voz, no momento seguinte, lerão por "ouvir contar" o que os primeiros escutaram a partir da leitura de primeira natureza.

A imagem indica, também, que, apesar do silêncio reiterado de décadas sobre as práticas (inclusive as de leitura) desses sujeitos históricos, vez por outra aparece uma imagem, um resto, um rastro, um vestígio mostrando que existe, de fato, muito mais correlação entre imprensa e escravidão do que poderíamos, a princípio, supor.

Se considerarmos o conhecimento como um valor intrinsecamente relacionado às possibilidades históricas de cada época, ou aos regimes de historicidade nos quais os homens estão imersos, o letramento dos escravos do Brasil do século XIX é uma página (quase) esquecida por razões que não dizem respeito apenas à dificuldade de recuperar esses indícios do passado. Em várias épocas, como adverte Agnes Heller (1993), há sempre algum conhecimento que foi considerado algo maldito, uma forma de transgressão moral, alguma coisa que não se podia falar ou revelar. Em diferentes idades anteriores, continua ela, sempre havia algo que um mortal não deveria conhecer. Assim, no século XXI, passados mais de 100 anos do fim da escravidão, talvez tenhamos distância suficiente para nos afastarmos da forma como se viu durante muito tempo os escravos e seus descendentes, podendo-se, agora, com um pouco menos de preconceito, admitir as múltiplas possibilidades culturais que partilhavam e legaram à sociedade.

A existência de leitores escravos é um acontecimento do passado histórico que, tendo sido esquecido por décadas, deve ser relembrado. 0 passado, sempre contido no presente pelas artimanhas da memória, faz com que se possa, em algum momento da nossa consciência histórica, relembrar aquilo que foi sistematicamente esquecido. "Os historiadores agem como psicanalistas da espécie humana, na medida em que transformam o esquecido em relembrado" (HELLER, 1993, p. 107). 0 passado não se constitui naquilo que é lembrado, mas naquilo que pode ser recordado. É isso que chamamos passado histórico.

Há vestígios e traços em múltiplas vozes que ecoam no presente. É preciso ir em direção a esses ecos. Está, no presente, o vestígio, a disponibilidade para percebê-lo como mensagem e a leitura que fazemos. Ao fornecer um tipo de compreensão/explicação para a mensagem, entretanto, oferecemos uma decifração do 
passado (entre múltiplas possíveis). Portanto, no nosso entendimento, as leituras e o letramento dos escravos do século XIX constituem-se em um tema da historiografia que é possível no presente também porque muitos pesquisadores realizaram diversos estudos desse período, colocando em xeque algumas interpretações limitadoras ${ }^{4}$. Além disso, está no nosso aqui e agora porque o grau de consciência histórica que adquirimos permite a sua visualização.

Se nos próprios periódicos há traços marcantes da possibilidade de leitura dos escravos, sobretudo nos anúncios publicados para denunciar suas fugas do cativeiro, há outros indícios desse mundo da leitura e do letramento em que estavam imersos em outros documentos menos evidentes. Na documentação anexa aos processos penais, Wissenbach (2002), por exemplo, encontrou cartas escritas pelo "escravo de ganho" chamado Claro, que era pedreiro, a pedido da também escrava Theodora (que não sabia ler nem escrever). Assim, mesmo podendo não ser leitores, nem escritores, sabiam como e em que circunstâncias deveriam utilizar os códigos escritos, sendo, portanto, letrados.

Como afirma Wissenbach (2002), em relação à escrita, o que é extensivo à leitura, estar imerso nesse mundo ligava-se direta ou indiretamente às sociabilidades existentes nas cidades, entre escravos, forros, negros nascidos livres e brancos pobres em um tempo em que "uns lêem, outros escutam, ou simplesmente veem, mas todos aproximam-se bem ou mal da escrita, todos percebem-na e experimentam sua presença" (FABRE, 1985, p. 233 apud WISSENBACH, 1998, p. 113)

Nos romances de época, há dezenas de descrições de cartas amorosas lidas e comentadas por jovens sinhazinhas a suas mucamas mais próximas. Ou de outros que são portadores frequentes dos "mandados", entre eles, os bilhetes e cartas a serem entregues a um outrem. Também nos textos ficcionais, os escravos emergem na cena das salas das casas grandes para servir aos seus senhores quando textos de romances ou dos periódicos da época estão sendo lidos e comentados em voz alta.

Num pequeno trecho perdido no meio de uma crônica, João do Rio se refere aos vendedores de livros "baratos e sarrabulhentos" que eram vendidos pela cidade no início do século e faz referência aos africanos que "há alguns anos" realizavam aquela tarefa. "Há alguns anos, esses vendedores não passavam de meia dúzia de africanos, espapaçados preguiçosamente como o João Brandão na Praça do Mercado" (RIO, 1987, p. 47).

0 africano nomeado pelo cronista não só estava em contato com os livros, como fazia da sua venda a sua ocupação. Como chegara ele a ser vendedor de livros? Quando seria esse tempo 
nomeado por João do Rio? Se as crônicas foram escritas quando o escritor trabalhava na Gazeta de Notícias e na Revista Kosmos, isto é, em 1904, João Brandão devia vender livros na Praça do Mercado desde os idos de 1880. Em meio às discussões em torno da questão do cativeiro, "um africano" vendia livros na Praça do Mercado.

Mas talvez o mais evidente signo da imersão dos escravos no mundo do letramento seja 0 documento que traduzia a sua liberdade. A carta de alforria era um escrito que 0 fazia sair do mundo da escravidão para 0 da possibilidade de liberdade. A "carta", como a chamavam comumente, um amontoado de letras que, mesmo imperceptíveis à possibilidade de leitura, era perceptível: um código, o escrito, firmava a possibilidade de ultrapassar a condição de escravo. Como destaca Wissenbach (2002, p. 119), a carta de alforria trazia para as palavras (escritas) uma espécie de sentido mágico e "aproximava-se aos escapulários e aos amuletos que os afro-brasileiros traziam consigo, no interior dos quais guardavam orações dedicadas a santos católicos e trechos dos livros sagrados dos muçulmanos".

Fugiu da cidade de Itapetininga o escravo de nome Luiz, cabra 22 anos, altura regular e corpulento, pés grandes, cabelos grenhos, olhos vivos e pequenos, falta de dentes na frente, $\underline{\text { sabe }}$ ler e escrever regularmente, fala bem e muito explicado, muito risonho e fica sempre com papéis nas algibeiras, gosta muito de recitar versos, é pedreiro e copeiro e costuma dizer que é forro, anda descalço. É de Macaé, Rio de Janeiro (Correio Paulistano, 18 agosto de 1877 apud SCHWARCZ, 1987, p. 141-142, grifo nosso).
Luiz, um escravo de 22 anos, sabia que não seria mais denunciado ao dizer que era forro. Será que os papéis que carregava na algibeira eram para dar a impressão que possuía ali, junto ao corpo, a sua carta de alforria? Afinal, "costumava dizer que era forro" e havia a necessidade de possuir 0 signo letrado da sua condição de livre. Será que falava tão bem e tão explicado porque sabia ler e escrever regularmente? 0 que significaria saber "ler e escrever regularmente"? Ficaria Luiz lendo seguidamente ou lia com pouca dificuldade?

Apesar da habilidade com a leitura e a escrita, misturava no seu cotidiano práticas da oralidade: recitava versos de cor, que foram aprendidos pela leitura ou práticas mneumônicas. Mas, mesmo que tivesse sido aprendida a partir da leitura, a poesia pertence inexoravelmente ao mundo da oralidade. Luiz recitava de cor porque o texto possuía a métrica verbal, como os ritmos da dança, dos instrumentos musicais e da melodia. Na poesia e na música encontra-se, segundo Havelock (1995), o complexo mundo das práticas orais. Não é por acaso que "mousiké" é a Musa Filha da Recordação.

Pedreiro, tinha conhecimento de códigos numéricos. Copeiro, sabia ainda outros signos do mundo abastado. Os dois ofícios exigiam conhecimentos múltiplos, todos saídos do mundo do letramento. Sobretudo a habilidade de servir a mesa significava definitivamente a redução do som ao espaço de imutabilidade. Mas Luiz continuava inserido em dois mundos: recitando 
suas poesias, falando bem e muito bem explicado, possuindo o riso solto, também carregava junto ao corpo as marcas de sua inserção no mundo da escrita.

Mesmo os pequenos escravos podiam conhecer 0 significado de possuir uma carta de alforria. Ser forro era ser escravo livre. Em 7 de setembro de 1874, o Correio Paulistano publicou sob o título "Fujão", o seguinte anúncio:

Pede-se a quem encontrar o menor Estevão, muito conhecido aqui dentro da cidade, fugido de casa há 8 dias, o favor de mandar encontrálo à rua da Esperança que será gratificado. Ele saiu com calça de algodão de inverno, jaqueta velha e camisa tudo sujo, desconfia-se estar pela Penha, Consolação ou pelas estradas, tem de 9 a 10 anos, é pardo. É escravo e por isso intitula-se às vezes forro (SCHWARCZ, 1987, p. 142, grifo nosso).

A cor, as vestes e as marcas da escravidão pelo corpo ou pela condição das roupas que portava (camisa tudo sujo) eram signos de estigmatização de sua condição escrava. Signos abertos ao olhar. Para poder permanecer oculto, havia que possuir outras marcas: a palavra falada era a fórmula encontrada para anunciar uma outra condição: a de forro.

\section{Moleque fugido.}

Desde quinta-feira anda fugido o escravo Silvestre, natural do Ceará, levou calça embranquecida. Costuma dar-se por livre, mudar de nome e alugar-se para qualquer serviço, outras vezes diz que é cativo de diversas pessoas sem declarar quem é o seu senhor [...] (Província de São Paulo, 25 abril 1878. In: Schwarcz, 1987, p. 141, grifo nosso).
Na descrição aparecem as muitas astúcias do pequeno Silvestre, que, apesar de não ter revelada a idade, tem a sua condição de criança indicada no título. Certamente, Silvestre não dominava os códigos letrados, mas estava imerso no universo do letramento. Assim, sabia que o nome designava a sua condição de escravo. Trocar de nome era ficar encoberto por outro código oral/escrito. Além disso, alternava na fala a sua própria condição: ora dizia-se livre, ora dizia-se cativo de diversas pessoas, mas sem desvendar a identidade de seu senhor. Astúcias de um mundo oral repleto de signos de uma ordem letrada.

\section{Leitores de múltiplas naturezas}

Vivendo num mundo marcado por um aprendizado que se fazia em espaços múltiplos e exteriores à escola, imersos nesse mesmo universo, realizando trocas culturais com outros grupos com os quais tinham aproximações, em maior ou menor escala, também para os escravos aprender a ler e a escrever ou se familiarizar com as letras impressas era uma ação de troca cultural entre eles e aqueles que dominavam com maior destreza esses códigos.

0 caso da jovem escrava Eduarda, citado por Morel (2008, p. 75), que segundo ele, "sintetiza como esses agentes históricos deixaram suas marcas no papel impresso", exemplifica o que estamos chamando leitura de terceira natureza e que era realizada pela maioria dos escravos que habitava as cidades. 
Perambulando pela rua, na manhã de 11 de fevereiro de 1886, com hematomas e feridas abertas no rosto e nos braços, marcas visíveis da tortura que lhe fora imposta por sua dona, Eduarda foi abordada por uma senhora que a dissuadiu de dirigir-se à Chefia da Polícia, aconselhando-a a ir até a redação da Gazeta da Tarde, no centro do Rio de Janeiro, "onde estaria mais segura e poderia ser ouvida". 0 jornal fora fundado pelo líder abolicionista José do Patrocínio, em 1881, ficando lá até 1887, quando deixa o periódico para fundar a Cidade do Rio, vendendo sua parte na sociedade.

0 episódio é contado minuciosamente por Morel (2008, p. 75-76), que destaca a forma como esta escrava e outra que ficara no mesmo cativeiro foram conduzidas até o juiz da $2^{\mathrm{a}}$ Vara Cível e, posteriormente, ao médico, para que currasse seus ferimentos do corpo, ao mesmo tempo em que Patrocínio divulgava para outros órgãos da imprensa 0 acontecimento. Formou-se um cortejo com líderes abolicionistas e alguns jornalistas conduzindo as torturadas e que se dirigiu às redações dos principais jornais da cidade: Vanguarda, Diário de Notícias, O Paiz, O Apóstolo, Gazeta de Notícias e Jornal do Commercio. "Não eram publicações antiescravistas, continua Morel, mas no dia seguinte abriram largo espaço em suas páginas e fizeram coro contra a violência cometida".

A escrava Eduarda não sabia ler, nem escrever, mas fora capaz de compreender quando a senhora que a abordou sugeriu que se dirigisse à redação do jornal de propriedade de José do Patrocínio. Compreendera que, fazendo isso, sua situação estaria mais bem resolvida. 0 que pensara ela nesse momento? Por que aceitou a sugestão? Certamente porque já ouvira falar no líder abolicionista e sabia que aquele jornal recebia reclamações e estava a favor dos escravos. Mas, mesmo que não soubesse nada disso, Eduarda ouviu falar naquele momento de um jornal para aonde poderia se dirigir. Compreendeu a informação, ou seja, percebeu o que significava um jornal abolicionista. Percebeu igualmente 0 simbolismo e a importância das letras impressas nessa sociedade, representados pelo periódico que a acolheria. Eduarda realizou nesse momento uma leitura de terceira natureza.

No fato narrado, observa-se também que os periódicos, para além da sua filiação ideológica, formavam um corpo uniforme em torno de um mesmo ideal: a divulgação de um acontecimento considerado como capaz de interessar a um público mais amplo e a construção desses impressos como porta-vozes. 0 caso de duas escravas que estavam sendo torturadas, quase até a morte, por uma senhora abastada, amante de um rico comerciante, tinha todos os ingredientes que poderiam interessar aos leitores: a tortura contra os indefesos, a situação de penúria e indigência das vítimas, o poderoso contra o fraco. Além disso, ao se solidarizarem com Patrocínio e o seu jornal, os periódicos, mesmo os que não 
eram claramente filiados à causa abolicionista, passavam a formar um bloco de poder, no sentido empregado por Gramsci (1991), constituindose numa única instituição e com um único propósito: possuir o poder de divulgar e de revelar o que ficaria oculto e, o mais importante, 0 de intermediar as causas dos fracos e dos oprimidos. Ganhavam a simpatia do público, reafirmavam seu lugar de poder e, em consequência, aproximavamse de outros grupos dominantes que igualmente tinham o poder de fala e de ação nessa sociedade.

Mas os escravos também podiam realizar uma leitura de segunda natureza, isto é, outro escravo ou outra pessoa podia ler trechos dos jornais, de livros, de papéis diversos para ele, como os escravos leitores já referidos da Revista Ilustrada. A leitura utilitária realizada por um outrem nesse momento os transformava em leitores. Muitos, entretanto, não eram leitores, nem sabiam escrever, mas manejavam com destreza os códigos inscritos no mundo do letramento. Não só os pedreiros e carpinteiros, não apenas os impressores e escreventes, não somente os vendedores das folhas impressas. Muitos outros estavam imersos num mundo onde as notícias corriam léguas, não apenas de boca em boca, mas também através dos impressos que, em profusão, eram editados em algumas cidades $^{5}$. As transformações que afetavam, sobretudo, as capitais pela circulação da palavra impressa não poderiam ficar ao largo desses personagens. Como mostra Havelock (1995), a fala letrada altera sempre 0 discurso da ação em favor da reflexão. 0 conteúdo daquilo que será comunicado passa a ser regido pela tecnologia utilizada, no caso a escrita. Com a escrita emerge a consciência letrada, o pensamento linear, a construção de visões permeadas pela maneira letrada de ver o mundo.

Já com a escrita transformada em letras impressas, outra mudança significativa se opera na cognição daqueles que dominam esses códigos. Exacerba-se a visualidade do mundo, já que as palavras impressas são apresentadas como imagens que se repetem. As palavras passam a ser unidades visuais que são aprisionadas num espaço: as materialidades dos impressos. A impressão dá também maior legibilidade ao texto, favorecendo a produção de uma leitura rápida e silenciosa. Com a impressão, abre-se a possibilidade de perceber o espaço como lugar de múltiplas visualidades e instaura-se, também pelos usos, a lógica da propriedade privada da palavra. Como enfatiza Eisentein (1998), com a impressão a palavra tornase produto, produzindo múltiplos efeitos sobre 0 pensamento e a expressão.

Além de um universo de letramento e letrado, estamos falando, portanto, de um mundo onde a multiplicidade dos impressos começava com mais intensidade a fazer parte do cotidiano. $0 \mathrm{~s}$ 
cartazes que se espalhavam pelos muros e paredes das cidades e os jornais e revistas que eram sobraçados pelos vendedores ambulantes ou que ficavam expostos nos quiosques multiplicavam a palavra impressa e faziam dela objeto do olhar.

Imersos nesse universo cultural, os escravos, mesmo sem saber ler e escrever, faziam parte de um mundo letrado e compreendiam e explicavam o mundo também a partir dessa lógica. Portanto, todos possuíam, em maior ou menor grau, capacidade de letramento.

Mas, quando usavam cotidianamente os códigos numéricos e alfabéticos para desempenhar as mais variadas tarefas, sua capacidade de entendimento dos códigos escritos era maior e é nesse sentido que enfatizamos possuírem signos mais visíveis desse letramento.

Assim, talvez seja mais correto falar em práticas de letramento, no plural, considerando que também não são unívocas. Essas habilidades advindas de uma mentalidade letrada eram aprendidas em múltiplos espaços: na rua, no cativeiro, na casa dos senhores. Devemos, portanto, considerar o letramento como algo diverso da leitura, isto é, da capacidade de alfabetização, uma vez que se pode não dominar o código escrito, mas saber a sua função na sociedade e fazer uso dele.

\section{Duplo mundo}

A inserção dos escravos nesse duplo mundo (oral e escrito) é frequentemente referenciada nos anúncios, como são também suas habilidades com os códigos da oralidade. Muitos faziam da música, do canto, da arte de tocar instrumentos marcas de seu mundo e eram elas que os proprietários igualmente destacavam nos anúncios de fugas como possibilidade de identificação dos escravos.

\begin{abstract}
A Joaquim de Sapaio Goes, conhecido por Quito de Sampaio, morador de Campinas, fugiu no dia 21 de dezembro de 1873 o escravo Rufino, crioulo da Bahia, idade 25 anos mais ou menos, altura regular, bem feito de corpo, cor fula, quase mulato, vermelho, cabelos grenhos, pouca barga, boa dentadura, tem o rosto bem bexigoso, tem 0 braço direito quebrado, perto da munheca, tem os pés muito largos, os dedos grandes muito abertos, é bem ladino, gosta de cantar e tem boa voz. Quem o prender e levar ao seu senhor, será gratificado. Protesta-se contra quem 0 tiver açoitado com o rigor da lei (Correio Paulistano, 29 janeiro 1878 apud SCHWARCZ, 1987, Apêndice, grifo nosso).
\end{abstract}

Nesse anúncio há muitos signos do mundo da escravidão. Rufino, um escravo que aceitou a palavra oficial, isto é, o português (daí "ladino"), fugiu não do cativeiro, mas de Quinto de Sampaio, o seu senhor, morador de Campinas. Rufino tinha no corpo a sua condição escrava impressa: 0 braço direito quebrado, os pés largos e os dedos abertos, decorrente de andar permanentemente descalço. Gostava de cantar e a sua boa voz era destacada, indicando que 0 som de seus cantos ecoava da senzala em direção à casa grande e que eram apreciados.

[...] Gregório, idade 26 anos, mais ou menos, mulato caboclo vermelho, boa dentadura, tendo falta de um dos da frente, altura baixo, grosso 
de corpo, tornando-se bem recalcado, cabelos corredios, bem barbado, tendo as sobrancelhas e bigodes muito serrados, o corpo muito cabeludo. Marinho, idade 25 anos, mais ou menos, alto, bem repartido de corpo, mulato claro, bonito de feições, quando fala ri-se, barba somente no queixo, boa dentadura, ambos são filhos do Ceará, e mostram muito no sotaque serem filhos do norte, ambos tocam viola, e usavam de precatas, foram comprados dos senhores Francisco \& Adão [...] (Idem. Grifo nosso)

Tendo nome, mas não tendo idade certa, podiam ser "bonito de feições", mulatos, caboclos, altos, baixos, gordos, magros, entre inúmeras indicações de sua aparência física. Mesmo no cativeiro, alguns tinham o riso solto e muitos faziam da música a extensão do ritmo temático de sua cultura também oral. 0 repertório cultural desses escravos, imersos ao mesmo tempo no mundo oral, governado pela lógica da efemeridade, incluía o ritmo, reproduzido pelos sons da fala e pelos sons da música, que se constituíam assim numa espécie de documentação oral dessa cultura (HAVELOCK, 1995, p. 108).

Os próprios sons que emanavam das ruas das cidades por aqueles dias e que causavam estranhamento aos que estavam há séculos inseridos mais profundamente nas práticas do letramento eram também indícios de uma vida se fazia igualmente pelos modos de contar, de falar e de ouvir.

Mauad (2008, p. 79), ao destacar a presença da publicidade na Corte, nos idos de 1850, reproduz as impressões do alemão Koseritz em relação ao movimento do Rio de Janeiro, nos seus "odores, ruídos e imagens". "A vida de rua no Rio faz sobre 0 estrangeiro, principalmente sobre 0 provinciano, uma impressão de aturdir. Os nervos da vista, do ouvido e do olfato do habitante do Rio são, naturalmente, longamente preparados contra tais impressões, mas 0 alienígena deve empregar meses para se habituar".

Falar na "equação oralidade e escrita", apropriando-nos aqui da expressão de Havelock (1995), é pensar, mais uma vez, em misturas e, sobretudo, em pluralidade. Não há uma única oralidade, assim como não há um letramento. Cada sociedade, em função das práticas e apropriações que desenvolve em seus processos comunicacionais, realiza maneiras de se comunicar particulares tanto do ponto de vista da palavra falada, como do ponto de vista do entendimento e do uso dos códigos escritos. Não há um mundo oral e outro mundo escrito, mas mundos da oralidade e do letramento.

Por outro lado, também não há excludência entre esses dois mundos. 0 fato de existir modos de comunicação escritos, práticas de transmissão alfabetizadas, não quer dizer que haja a morte dos modos orais. Da mesma forma, o fato de existir já de maneira extensiva uma tecnologia da impressão que se materializa em livros, panfletos, cartazes, jornais e revistas não acaba com o mundo manuscrito mesmo nos impressos. 0 exemplo das revistas e dos jornais ilustrados que, por força das limitações técnicas, completavam a imagem com legendas escritas 
de forma manuscrita, mostra que a impressão dos periódicos coexistiu com a forma manuscrita inserida também nesses periódicos. Mais uma vez observamos um mundo de misturas, no qual as tecnologias coexistem em modos de comunicação.

A oralidade coexiste com o letramento, da mesma forma que as letras impressas coexistem nos periódicos com as manuscritas. A leitura em voz alta é talvez o exemplo mais simples de se pensar essa confluência do primeiro caso. Falar em letramento e oralidade é se referir a usos, 0 que nos obriga a pensar em sociedades, sujeitos e práticas sociais, não produzindo a generalização dos conceitos (THOMAS, 2005). No segundo caso, os jornais ilustrados com suas grandes imagens tomando inteiramente por vezes até duas páginas, onde 0 traço visual convivia com uma explicação do mundo manuscrito e onde nas outras páginas figurava a materialidade do mundo da impressão, são um bom exemplo da coexistência das tecnologias manuscritas e impressas.

Assim, mesmo aqueles que manejavam muitos códigos letrados e que faziam parte desse mesmo mundo por possuírem conhecimentos amplos ou restritos de leitura continuavam utilizando os códigos de uma cultura predominantemente oralizada.

Theodoro, um escravo pardo e baixo, de 22 anos, possuía muitas marcas desse mundo, apesar de saber ler números. Lia e sabia lidar com máquinas de corte, mas também fazia conta de memória, sabia música e tocava flauta e violão.
Todas essas habilidades dão conta de um universo mental predominantemente oral e das múltiplas misturas que convivem num território perpassado pelo letramento, mas que conserva fortemente as marcas da oralidade.

Acha-se fugido desde $1^{\circ}$ de março do corrente, o escravo Theodoro, pardo, baixo, cabelos corridos e de boa figura, bem feito de corpo, bons dentes e começando a barbear e tendo mais ou menos 22 anos, pagem de serviço doméstico acostumado a lidar com animais, copeiro, entende do ofício de carpinteiro, sabe lidar com máquinas de corte, lê números e faz conta de memória, sabe música, canta e toca flauta e violão e leva-o corpo só roupa de serviço (Correio Paulistano, 6 maio 1880 apud SCHWARCZ, 1987, p. 143, grifo nosso).

Já Ladisláu e Marcos, ambos jovens, pertenciam a múltiplos universos: o mundo da escravidão era o ponto comum entre eles. Mas, enquanto 0 primeiro era escravo de roça, o segundo dominava muitos códigos do letramento e também do universo da escrita e da leitura.

\section{0:000 Rs.}

Gratifica-se com a quantia acima a quem prender e entregar ao abaixo assinado, em Campinas, os escravos seguintes: Ladisláu, 24 anos, preto estatura regular, bons dentes, prosa e muito risonho, apto para o serviço de roça e cozinha. É natural de Magé, província do Rio, e fugiu da estação de Santa Bárbara em maio de 1876. Marcos, 27 anos, estatura regular, corpo reforçado, cor parda bem clara, cabelos pretos, finos e anelados, pouca barba e pequeno buço. Passa por domador de animais, sabe ler e escrever, entende de cozinha, de pedreiro e de carpinteiro. É natural do Rio Grande do Sul e fugiu em novembro de 1875 da estação de Santa Bárbara. Campinas, 22 de maio de 1878. João 
J. de Araújo Vianna (Província de São Paulo, 11 junho 1878 apud SHWARCZ, 1987, Apêndice, grifo nosso).

Portanto, entre Ladisláu e Marcos havia muitas semelhanças, mas também profundas diferenças. Ambos partilhavam a condição de escravos, eram jovens, propriedades do mesmo dono e fugiram do mesmo lugar. Ladisláu se destacava pela forma como era capaz de se anunciar - "passa por domador de animais" -, pelos ofícios que dominava e para os quais era imprescindível pelo menos o conhecimento numérico e, sobretudo, por saber ler e escrever.

Mais uma vez, vemos aqui que 0 ato enunciativo pode ser ato de encobrimento de uma condição que não pode ser revelada. Era indispensável a Marcos se enunciar dentro de uma identidade ocupacional. Sua condição real, a de escravo, deveria ser silenciada. Mas por que se dizia "domador de animais"?

Não sabemos o que Marcos efetivamente lia, nem como manejava a leitura e a escrita. Mas o fato de o seu dono destacar no anúncio essas habilidades, apresentadas como traços característicos capazes de identificá-lo, permite supor que ele realizava com frequência a leitura e a escrita. Era também por meio da leitura e da escrita e não apenas pela "estatura regular, corpo reforçado, cor parda bem clara, cabelos pretos, finos e anelados, pouca barba e pequeno buço" que poderia vir a ser descoberto e denunciado.

\section{Vestígios quase apagados...}

Mas porque, apesar de todos esses vestígios significantes que indicam as práticas de leitura e a imersão no mundo do letramento dos escravos no Brasil do século XIX, esse é ainda um tema (quase) esquecido? Morel (2008) chega mesmo a perguntar se, ao não admitirem a possibilidade de ações, leituras e recepções dos impressos por parte dos escravos e libertos, não estariam os pesquisadores reproduzindo formas de dominação?

Claro que há essa possibilidade, mas é preciso considerar ainda as dificuldades de recuperar esses indícios, ainda mais porque a memória e a sua construção para a história são exercícios dos que possuem voz na sociedade e produzem documentos para o futuro. Assim, as marcas da leitura plural e das apropriações das mensagens que circulavam na sociedade se referem, de maneira quase que exclusiva, aos que eram produtores daqueles discursos.

A voz dos escravos e o seu pensamento, que era produzido pela compreensão do mundo que efetivamente exercitavam, figuram num silêncio documental difícil de ser ultrapassado. Como não são produtores de texto, comunicando-se por meio das formas orais, sempre silenciosas do ponto de vista da produção de documentos, não deixaram rastros evidentes de como se relacionavam com os impressos e como realizavam suas leituras e apropriações ${ }^{6}$. 
Somente considerando os vestígios do passado como possíveis mensagens - e para isso há que haver uma consciência histórica no presente que tenha disponibilidade para visualizar suas leituras e interpretações - é possível recuperar essa voz e as formas de compreensão do mundo que exercitavam em contato com uma sociedade perpassada pelos impressos. É preciso uma predisposição, no tempo presente, para pensar os escravos não apenas como objetos, mas como sujeitos históricos que viviam num mundo de múltiplas vozes.

Há que se considerar também que as práticas de leitura do mundo dos escravos do século XIX eram profundamente diversas das nossas. Os impressos passaram a circular com maior intensidade apenas após a Independência, isto é, poucas décadas depois do período que estamos considerando. Havia permanências marcantes dos modos orais de comunicação e confluências específicas entre o mundo oral e o mundo letrado decorrentes também da historicidade dessa sociedade.

Mesmo os letrados brancos realizavam suas leituras em voz alta e em ambientes públicos. 0 compartilhamento dos jornais por um único leitor era prática corriqueira. Os jornais eram vendidos nas tipografias e livrarias que passaram a ser frequentadas por redatores e leitores, tornando-se pontos de venda dos impressos, lugares de prática de leituras coletivas e dos comentários delas decorrentes. Cartazes e papéis passaram a circular pelas ruas de maneira intensiva, incorporando-se ao cotidiano da população (MOREL, 2003, p. 45). Naquelas cidades, o manuscrito, 0 oral e 0 impresso divulgavam os fatos e as informações. Mas havia, sobretudo, a prevalência da oralidade que fazia com que as práticas de leitura se caracterizassem também pelas misturas dos modos orais e letrados, em função de um mundo profundamente diferente do nosso.

As práticas sociais da leitura podem se manifestar de múltiplas maneiras. Podese ler silenciosamente, ruidosamente ou deliberadamente em voz alta para outro. Podese igualmente ler rapidamente, 0 que denota o manejo extensivo dos códigos escritos, ou soletrando letra por letra, decifrando-se cada palavra de forma isolada, o que dificulta, na maioria das vezes, a compreensão final. Pode-se também manejar os códigos da escrita de forma titubeante. Há, sempre, em qualquer sociedade, múltiplas práticas de leitura.

Há que se considerar também que a materialidade do texto influencia a maneira como se pode realizar essa prática. 0s contextos de leitura, escrita à mão ou escrita sob a forma impressa, por exemplo, induzem a diferentes níveis de habilidades. Ler um texto manuscrito para quem não maneja com destreza 0 código pode representar dificuldade suplementar, ainda mais quando a produção é de um outrem com limitações em relação à escrita. Por outro lado, um texto impresso pode facilitar 0 entendimento. 
E mais: a leitura de um livro ou de um jornal não é feita da mesma forma. A própria expectativa em relação ao texto induz à maneira diferenciada de realizar as leituras. Há sempre diferentes níveis de letramento e o letramento não é uma habilidade unívoca.

As habilidades de leitura e escrita dos escravos estavam contidas habitualmente nos anúncios que informavam suas fugas e prometiam recompensas a quem os localizasse ou ameaçava com a letra da lei aqueles que os protegessem. Nos que anunciavam a venda, aluguel ou leilão, elas não eram destacadas: 0 que se particularizava eram suas características físicas. As "peças" - como muitas vezes se referiam aos escravos - eram valorizadas se fossem "robustas, fortes, sadias, inteligentes e boas para qualquer serviço", sendo comercializadas, como destaca Schwarcz, como "coisa" e objeto (1987, p. 135). "Na rua da Consolação 72, há 38 peças para vender [...] todos bonitas peças. Vende-se barato para liquidar" (Correio Paulistano, 9 maio de 1880 apud SCHWARCZ, 1987, p. 135, grifos nossos).

Escravos bons: Vende-se três excelentes escravos, sendo: um moleque de 16 para 17 anos de idade, bonita figura, outro de 35 anos, habilíssimo, destro de serviço de lavoura e uma creoula de 14 para 15 anos, bonita estampa". (Correio Paulistano. 9 maio 1880 apud SCHWARCZ, op. cit., p. 135, grifos nossos).

Ou ainda:

Muita atenção. Vende-se uma elegante e bonita mucama recolhida e de casa particular que tem muitos préstimos com 18 anos de idade, sadia, sabe ainda engomar, fazer tuiote, costurar e cortar figurino. 0 motivo da venda não desagradará o comprador (Província de São Paulo, 25 setembro 1877 apud SCHWARCZ, op. cit., p. 135 , grifos nossos).

Os que sabiam ler possuíam outras habilidades próprias dessa imersão no mundo letrado.

Havia uma espécie de invasão do mundo letrado no mundo não letrado. Novos hábitos e novas habilidades possibilitadas pelo raciocínio, que acionava formas abstratas de ver e viver 0 mundo, são adicionados a uma cultura governada antes de tudo pelo ritmo da fala. A escrita, como enfatiza Havelock (1995), permite 0 acionamento de três atos mentais: comparação abstrata, observação de objetos físicos e possibilidade de pensamento relacional. Com a cultura letrada, alarga-se a percepção visual, mas a memória acionada continua sendo de natureza acústica. 0 letramento transforma 0 conteúdo da mente humana. Com a utilização extensiva de um dispositivo mneumônico mecânico (a escrita), instaura-se 0 esquecimento. Esquecer não traz mais prejuízo, por que se supõe que o que deveria ser lembrado pode ser registrado e fixado pela escrita que se transforma numa economia da memória. Alivia-se o cérebro da memorização, libertando-o para o pensamento conceitual (HAVELOCK, 1995, p. 83-85).

Escravo - fugiu de Bierrenbach \& Irmãos, de Campinas, no dia 2 de setembro deste ano, 0 mulato Rodolpho, de 24 anos, estatura média para baixo, corpo reforçado, fala bem, pisar firme [...] é muito ativo e inteligente, natural de Campos (RJ), professor chapeleiro mas sabe 
coser em máquina de costura, tendo trabalhado com máquina a vapor no que é prático. Sabe ler (Correio Paulistano, 11 setembro 1877 apud SCHWARCZ, p. 142, grifos nossos).

\begin{abstract}
A leitura possibilitava a Rodolpho adquirir outros conhecimentos. Sabia manejar um artefato tecnológico da indústria daqueles tempos, a máquina de costura, além de deter conhecimentos superiores de chapelaria.
\end{abstract} No manejo de outra máquina, símbolo da industrialização, a máquina a vapor, tinha conhecimentos práticos. Além disso, "falava bem, pisava firme e era muito ativo e inteligente". As qualificações atribuídas por seu proprietário, sobretudo o atributo da inteligência, advinha do fato de manejar as letras impressas? Certamente. Para o dono de Rodolpho, parecia não ser comum um escravo com tantas habilidades e dominando tantos saberes abstratos. Será que Rodolpho "pisava firme" também por ter consciência disso?

\section{Conclusão}

Como sujeitos inseridos num mundo no qual a equação oralidade-escrita promovia, sobretudo, misturas, muitos escravos do século XIX desenvolveram capacidades de letramento, outros tantos submergiram no mundo das letras impressas, transformando-se em público, talvez não almejados pelos que produziam essas mesmas letras impressas. Num mundo onde ser letrado significava ocupar uma posição superior na hierarquia da sociedade, como admitir que os escravos fossem leitores? Como imaginá-los como público daqueles impressos?
Mas o aparecimento cada vez mais recorrente de publicações que faziam da ilustração a mola fundamental da divulgação dos acontecimentos do momento, como a Revista Ilustrada, mostra também que o letramento se alargara. Mostra também que a impressão estava diante dos olhos de muitos. A leitura conduz a percepção para a visualidade. A impressão transforma a palavra em coisa visual, fazendo com que a própria compreensão e percepção do mundo sejam, sobretudo, governadas pela visualidade. Ainda que a memória continue acionando aspectos acústicos, como já enfatizamos, há uma mudança fundamental na mente dos leitores. Passa-se a ver o mundo também a partir da imobilidade dos traços escritos sob a forma de letras que são, antes de tudo, visuais.

Assim, na sequência de uma leitura extensiva e de formas múltiplas de impressão que se espraiam pela sociedade, exacerba-se a possibilidade de decifrar e informar sobre as coisas do mundo através de formas visuais. Essa é também uma explicação para o surgimento de publicações como a Revista Ilustrada, que no final dos anos 1880 chegaria a publicar quatro mil exemplares, número que, segundo afirmavam na edição de 31 de dezembro de 1889, "jamais foi atingindo por nenhum jornal ilustrado na América do Sul". 


\section{Referências}

BALABAN, Marcelo. Poeta do lápis: a trajetória de Angelo Agostini no Brasil. 2005. Tese (Doutorado em História)- Universidade de Campinas, Campinas, 2005.

CHARTIER, Roger. A história cultural: entre práticas e representações. Lisboa: Difel, 1990.

EISENSTEIN, Elisabeth. A Revolução da cultura imprensa no 0cidente: os primórdios da Europa Moderna. São Paulo: Ática, 1998.

FONSECA, Marcus Vinícius. Educação dos negros. Bragança Paulista: EDUSF, 2002.

GRAMSCI, Antonio. Maquiavel, a política e o Estado moderno. Rio de Janeiro: Civilização Brasileira, 1991.

HAVELOCK, Eric. A equação oralidade-cultura escrita: uma fórmula para a mente moderna. In: OLSON, David R.; TORRANCE, Nancy (orgs.). Cultura escrita e oralidade. São Paulo: Ática, 1995.

HELLER, Agnes. Uma teoria da história. Rio de Janeiro: Brasiliense, 1993.

MAUAD, Ana Maria. Poses e flagrantes: ensaios sobre história e fotografia. Niterói: EDUSP, 2008.

MORAIS, Christianni Cardoso. Ler e escrever: habilidades de escravos e forros? Comarca do Rio das Mortes, Minas Gerais, 1731-1850. Revista Brasileira de Educação, Belo Horizonte, v. 12, n. 36, p. 493-550, set. - dez. 2007.

MOREL, Marco; BARROS, Mariana G. M. de. Palavra, imagem e poder: 0 surgimento da imprensa no Brasil do século XIX. Rio de Janeiro: DP\&A, 2003. Imprensa e escravidão no Brasil do século

XIX. In: LUSTOSA, Isabel (org.). Imprensa, história e literatura. Rio de Janeiro: Casa de Rui Barbosa, 2008. MOYSÉS, Sarita. Literatura e história. Revista Brasileira de Educação, Belo Horizonte, n. 0, p. 5362, set. - dez. 1995.
PAIVA, Eduardo França. Leituras (im)possíveis: negros e mestiços leitores na América portuguesa. In: COLÓQUIO INTERNACIONAL POLÍTICA, NAÇÃO E EDIÇÃO, 2003, Belo Horizonte. Anais... Belo Horizonte: Programa de Pós-Graduação em História, Universidade Federal de Minas Gerais, 2003. v. 1.

REIS, João José. Rebelião escrava no Brasil: a história do levante dos malês em 1835. São Paulo: Companhia das Letras, 2003.

RIO, João do. A alma encantadora das ruas. Rio de Janeiro: Secreatraia Municipal de Cultura, 1987.

RIOS FILHO, Adolfo Moraels de los. 0 Rio de Janeiro imperial. Rio de Janeiro: Topbooks; Univercidade, 2000.

SCHWARCZ, Lilian. Retrato em branco e preto: jornais, escravos e cidadãos em São Paulo. São Paulo: Cia das Letras, 1987.

SODRÉ, Werneck Nelson. História da Imprensa no

Brasil. Rio de Janeiro: Civilização Brasileira, 1966.

THOMAS, Roslind. Letramento e oralidade na Grécia Antiga. São Paulo: Odysseus, 2003.

WISSENBACH, Maria Cristina Cortez. Cartas, procurações, escapulários e patuás: os múltiplos significados da escrita entre escravos e forros na sociedade oitocentista brasileira. Revista Brasileira de História da Educação, Campinas, n. 4, p. 103-122, jul. - dez. 2002.

\section{Sonhos africanos, vivências ladinas:} escravos e forros em São Paulo (1850-1880). São Paulo: HUCITEC; História Social / USP, 1998. 


\begin{tabular}{|l|l|l|}
\cline { 2 - 3 } & $\begin{array}{l}\text { Literate slaves: } \\
\text { a (almost) forgotten page }\end{array}$ & $\begin{array}{l}\text { Esclavos letrados: } \\
\text { una página (casi) olvidada }\end{array}$ \\
\hline $\begin{array}{l}\text { Abstract } \\
\text { The article intends to demonstrate that, although } \\
\text { little referred, the reading and writing of the slaves } \\
\text { in the nineteenth-century Brazil can be perfectly } \\
\text { retrieved from multiple indices. The stigmatization } \\
\text { of the slaves' immersion in a world in which orality } \\
\text { has always prevailed covers innumerous possibilities } \\
\text { of literacy and reading in a society crossed over by } \\
\text { printed matter. } \\
\text { Keywords } \\
\text { Salves. Reading. Print. }\end{array}$ & $\begin{array}{l}\text { Resumen } \\
\text { El artículo intenta mostrar que, aunque poco } \\
\text { estudiadas, la lectura y la escritura de los esclavos } \\
\text { del siglo XIX en Brasil puede ser perfectamente } \\
\text { recuperada a partir de múltiples indicaciones. El } \\
\text { estigma de la inmersión en un mundo de esclavos } \\
\text { cuya prevalencia fue verbal oculta sus múltiples } \\
\text { posibilidades de la lectura y de letramiento en } \\
\text { una sociedad permeada por la impresión. }\end{array}$ \\
\hline
\end{tabular}




\section{Expediente}

A revista E-Compós é a publicação científica em formato eletrônico da Associação Nacional dos Programas de Pós-Graduação em Comunicação (Compós). Lançada em 2004, tem como principal finalidade difundir a produção acadêmica de pesquisadores da área de Comunicação, inseridos em instituições do Brasil e do exterior.
E-COMPÓS I www.e-compos.org.br I E-ISSN 1808-2599

Revista da Associação Nacional dos Programas de Pós-Graduação em Comunicação. Brasília, v.12, n.1, jan./abr. 2009.

A identificação das edições, a partir de 2008 passa a ser volume anual com três números.

\section{CONSELHO EDITORIAL}

\section{Afonso Albuquerque}

Universidade Federal Fluminense, Brasil

Alberto Carlos Augusto Klein

Universidade Estadual de Londrina, Brasi

Alex Fernando Teixeira Primo

Universidade Federal do Rio Grande do Sul, Brasil

\section{Alfredo Vizeu}

Universidade Federal de Pernambuco, Brasil

Ana Carolina Damboriarena Escosteguy

Pontifícia Universidade Católica do Rio Grande do Sul, Bras

Ana Silvia Lopes Davi Médola

Universidade Estadual Paulista, Brasil

André Luiz Martins Lemos

Universidade Federal da Bahia, Brasil

Ângela Freire Prysthon

Universidade Federal de Pernambuco, Brasil

Antônio Fausto Neto

Universidade do Vale do Rio dos Sinos, Brasil

Antonio Carlos Hohlfeldt

Pontifícia Universidade Católica do Rio Grande do Sul, Brasil

Arlindo Ribeiro Machado

Universidade de São Paulo, Brasil

César Geraldo Guimarães

Universidade Federal de Minas Gerais, Brasil

Cristiane Freitas Gutfreind

Pontifícia Universidade Católica do Rio Grande do Sul, Brasil

Denilson Lopes

Universidade Federal do Rio de Janeiro, Brasil

Eduardo Peñuela Cañizal

Universidade Paulista, Brasi

Erick Felinto de Oliveira

Universidade do Estado do Rio de Janeiro, Brasil

Francisco Menezes Martins

Universidade Tuiuti do Paraná, Brasil

Gelson Santana

Universidade Anhembi/Morumbi, Brasi

Hector Ospina

Universidad de Manizales, Colômbia

leda Tucherman

Universidade Federal do Rio de Janeiro, Brasil

Itania Maria Mota Gomes

Universidade Federal da Bahia, Brasil

Janice Caiafa

Universidade Federal do Rio de Janeiro, Brasil

Jeder Silveira Janotti Junior

Universidade Federal da Bahia, Brasil
João Freire Filho

Universidade Federal do Rio de Janeiro, Brasil

John DH Downing

University of Texas at Austin, Estados Unidos

José Luiz Aidar Prado

Pontifícia Universidade Católica de São Paulo, Brasil

José Luiz Warren Jardim Gomes Braga

Universidade do Vale do Rio dos Sinos, Brasil

Juremir Machado da Silva

Pontifícia Universidade Católica do Rio Grande do Sul, Brasil

Lorraine Leu

University of Bristol, Grã-Bretanha

Luiz Claudio Martino

Universidade de Brasília, Brasil

Maria Immacolata Vassallo de Lopes

Universidade de São Paulo, Brasil

Maria Lucia Santaella

Pontifícia Universidade Católica de São Paulo, Brasil

Mauro Pereira Porto

Tulane University, Estados Unidos

Muniz Sodre de Araujo Cabral

Universidade Federal do Rio de Janeiro, Brasil

Nilda Aparecida Jacks

Universidade Federal do Rio Grande do Sul, Brasil

Paulo Roberto Gibaldi Vaz

Universidade Federal do Rio de Janeiro, Brasil

Renato Cordeiro Gomes

Pontifícia Universidade Católica do Rio de Janeiro, Brasil

Ronaldo George Hela

Universidade do Estado do Rio de Janeiro, Brasil

Rosana de Lima Soares

Universidade de São Paulo, Brasil

Rossana Reguillo

Instituto Tecnológico y de Estudios Superiores do Occidente, México

Rousiley Celi Moreira Maia

Universidade Federal de Minas Gerais, Brasil

Sebastião Carlos de Morais Squirra

Universidade Metodista de São Paulo, Brasi

Simone Maria Andrade Pereira de Sá

Universidade Federal Fluminense, Brasil

Suzete Venturelli

Universidade de Brasília, Brasil

Valério Cruz Brittos

Universidade do Vale do Rio dos Sinos, Brasil

Veneza Mayora Ronsini

Universidade Federal de Santa Maria, Brasil

Vera Regina Veiga França

Universidade Federal de Minas Gerais, Brasil
COMISSÃO EDITORIAL

Ana Gruszynski I Universidade Federal do Rio Grande do Sul, Brasil

Rose Melo Rocha I Escola Superior de Propaganda e Marketing, Brasil

CONSULTORES AD HOC

Alberto Schneider I Visitante Tokyo University

Alexandre Rocha da Silva I Universidade Federal do Rio Grande do Sul, Brasil

Fernanda Bruno I Universidade Federal do Rio de Janeiro, Brasil

Ida Stumpf I Universidade Federal do Rio Grande do Sul, Brasil

Kati Caetano I Universidade Tuiuti do Paraná, Brasil

Laura Cánepa I Universidade Anhembi Morumbi, Brasi

Malena Contrera I Universidade Paulista, Brasil

Sandra Gonçalves I Universidade Federal do Rio Grande do Sul, Brasil

Vicente Gosciola I Universidade Anhembi Morumbi, Brasil

REVISÃO DE TEXTO E TRADUÇÃo I Everton Cardoso

EDITORAÇ̃̃o ELETRÔNICA I Raquel Castedo
COMPós I www.compos.org.br

Associação Nacional dos Programas de Pós-Graduação em Comunicação

Presidente

Erick Felinto de Oliveira

Universidade do Estado do Rio de Janeiro, Brasil erickfelinto@uol.com.br

Vice-presidente

Ana Silvia Lopes Davi Médola

Universidade Estadual Paulista, Brasil

asilvia@faac.unesp.br

Secretária-Geral

Denize Correa Araújo

Universidade Tuiuti do Paraná, Brasil

denizearaujo@hotmail.com 